University of Nebraska - Lincoln

DigitalCommons@University of Nebraska - Lincoln

Faculty Publications: Department of Entomology

$8-28-2003$

\title{
Genetic similarity among pheromone and voltinism races of Ostrinia nubilalis (Hubner) (Lepidoptera: Crambidae)
}

\author{
P. C. R. G. Marcon \\ University of Nebraska-Lincoln \\ David B. Taylor \\ University of Nebraska-Lincoln, dave.taylor@ars.usda.gov \\ C. E. Mason \\ University of Delaware \\ R. L. Hellmich \\ USDA-ARS, richard.hellmich@ars.usda.gov \\ Blair Siegfried \\ University of Nebraska-Lincoln, bsiegfried1@ufl.edu
}

Follow this and additional works at: https://digitalcommons.unl.edu/entomologyfacpub

Part of the Entomology Commons

Marcon, P. C. R. G.; Taylor, David B.; Mason, C. E.; Hellmich, R. L.; and Siegfried, Blair, "Genetic similarity among pheromone and voltinism races of Ostrinia nubilalis (Hubner) (Lepidoptera: Crambidae)" (2003). Faculty Publications: Department of Entomology. 149.

https://digitalcommons.unl.edu/entomologyfacpub/149

This Article is brought to you for free and open access by the Entomology, Department of at DigitalCommons@University of Nebraska - Lincoln. It has been accepted for inclusion in Faculty Publications: Department of Entomology by an authorized administrator of DigitalCommons@University of Nebraska - Lincoln. 


\section{Genetic similarity among pheromone and voltinism races of Ostrinia nubilalis (Hübner) (Lepidoptera: Crambidae)}

\author{
P. C. R. G. Marçon, ${ }^{1 *}$ D. B. Taylor, ${ }^{2}$ C. E. Mason, ${ }^{3}$ \\ R. L. Hellmich and B. D. Siegtried" \\ ${ }^{1} 202$ Plant Industry Bldg., Department of Entomology, \\ University of Nebraska-Lincoln, Lincoln, Nebraska, \\ USA ${ }^{2}$ Midwest Livestock Insects Research Laboratory, \\ USDA-ARS, Department of Entomology, University of \\ Nebraska-Lincoln, Lincoln, Nebraska, USA; \\ ${ }^{3}$ Department of Entomology and Applied Ecology, \\ University of Delaware, Newark, Delaware, USA; ${ }^{4}$ Corn \\ Insects and Crop Genetics Research Unit, USDA-ARS, \\ Department of Entomology, lowa State University, \\ Ames, lowa, USA
}

\begin{abstract}
The genetic variability of seven European corn borer populations, Ostrinia nubilalis, from North America and Europe was assessed by polymerase chain reaction-restriction fragment length polymorphism (PCRRFLP) analysis and DNA sequencing. The nuclear ribosomal internal transcribed spacer 1 (ITS-1) region ( $\approx 500$ base pair [bp]) and four mitochondrial (mtDNA) regions (1550 bp total) were examined. The smartweed borer, Ostrinia obumbratalis, and south-Western corn borer, Diatraea grandiosella, were used for comparisons. Of 106 restriction sites identified (80 in mtDNA and 26 in ITS-1), none differentiated geographical populations, pheromone races, or voltine ecotypes of the European corn borer. The lack of variation in the ITS-1 of European corn borer was confirmed by DNA sequence analysis. The genetic similarity of European corn borer populations, despite their wide geographical range and physiological differences, may be explained by a relatively recent origin for the voltinism and pheromone races, gene flow among races, and/or expansion from genetic bottlenecks.
\end{abstract}

"Present address: DuPont Agricultural Products, Stine-Haskell Research Center, Newark, DE 19714, USA.

Received 27 April 1998; accepted 29 July 1998. Correspondence: Dr B. D. Siegfried, Rm. 202, Plant Industry Bldg., Department of Entomology, University of Nebraska-Lincoln, Lincoln, NE 68583-0816, USA. E-mail: bds@ unlinfo.unl.edu
Keywords: internal transcribed spacer, mitochondrial DNA, Ostrinia nubilalis, pheromone races, voltinism ecotypes.

\section{Introduction}

The European corn borer, Ostrinia nubilalis (Hübner), is of agricultural significance in much of the Northern hemisphere, including Europe, Asia, Northern Africa, North America, the Philippines, Guam and Japan (Beck, 1987). It affects the production of maize, as well as other crops including sorghum, cotton, potatoes and many vegetables. Overall, yield losses and control expenditures associated with the European corn borer are estimated to exceed US $\$ 1$ bn annually (Mason et al., 1996). The European corn borer is native to Southern Europe (Beck, 1987) and is believed to have been introduced into North America between 1909 and 1914, probably on broom corn imported from Hungary or Italy (Vinal, 1917). However, based on differences in voltinism and sex pheromone composition among European corn borer ecotypes and races, it is likely that multiple introductions occurred (Showers, 1993). In the 80 years since its introduction, the European corn borer has spread rapidly northward into Canada, westward to the Rocky Mountains, and southward to Florida and Mexico (Mason et al., 1996).

Two pheromone races of the European corn borer have been identified in North America. Both use 11tetradecenyl acetate isomers ( $E$ and $Z$ ) as sex pheromones; females of the $Z$ strain produce a blend with an $E: Z$ ratio of 3:97, whereas the ratio in females of the $E$ strain ranges from 97:3 (DuRant et al., 1995) to $99: 1$ (Roelofs et al., 1987). Liebherr \& Roelofs (1975) demonstrated the selective mating of European corn borer pheromone races, based not only upon their isomeric blends, but also on mating periodicity. Nevertheless, hybrid moths have been produced in the laboratory and are found in nature in areas where the races occur sympatrically (Roelofs et al., 1987). The $Z$ race predominates over most of the range in Europe and North America, whereas the $E$ strain is found in Switzerland, Italy and Eastern North America, from Massachusetts 
Table 1. European corn borer populations studied.

\begin{tabular}{|c|c|c|c|c|c|c|c|c|}
\hline \multirow[b]{2}{*}{ Collection } & \multirow[b]{2}{*}{$\begin{array}{l}\text { Voltine } \\
\text { ecotype }\end{array}$} & \multirow[b]{2}{*}{$\begin{array}{l}\text { Pheromone } \\
\text { race }\end{array}$} & \multicolumn{3}{|c|}{ Pheromone gland analysis ${ }^{a}$} & \multicolumn{3}{|c|}{ Collection } \\
\hline & & & $\begin{array}{l}\text { Generation } \\
\text { tested }\end{array}$ & $N$ & $\begin{array}{l}\text { Frequency } \\
Z \text { allele }\end{array}$ & Stage & $\begin{array}{l}\text { Host } \\
\text { plant }\end{array}$ & $\begin{array}{l}\text { Date } \\
\text { collected }\end{array}$ \\
\hline Burleigh Co., ND ${ }^{d}$ & Univoltine & $Z^{b}$ & - & - & - & Larva & Corn & Jul 1995 \\
\hline Hooper, NE & Biovoltine $^{c}$ & $Z^{\mathrm{b}}$ & - & - & - & Adult & Corn & Jun 1995 \\
\hline Selingsgrove, $\mathrm{PA}^{\mathrm{e}}$ & Uni- \& Bivoltine $e^{c}$ & $Z$ and $E$ & $\mathrm{~F}_{2}$ & 20 & 0.90 & Egg & Corn & Jun 1995 \\
\hline Bouckville, NY & Univoltine & $z$ & $\mathrm{~F}_{2}$ and $\mathrm{F}_{4}$ & 100 & 1.00 & Larva & Corn & Feb 1989 \\
\hline Geneva, $N Y^{\prime}$ & Bivoltine & $E$ & $\mathrm{~F}_{2}$ and $\mathrm{F}_{4}$ & 100 & 0.00 & Larva & Corn & Dec 1988 \\
\hline Plymouth, $\mathrm{NC}^{\mathrm{g}}$ & Multivoltine $^{\mathrm{c}}$ & $E$ and $Z$ & $\mathrm{~F}_{3}$ & 68 & 0.18 & Larva & Potato & Jun 1995 \\
\hline Lombardia, Italy ${ }^{n}$ & Bivoltine $^{c}$ & $E$ and $Z$ & $F_{3}$ & 27 & 0.44 & Larva & Corn & Jul 1995 \\
\hline
\end{tabular}

${ }^{a}$ Female pheromone gland analyses for PA, NC and Europe by CEM; pheromone gland analyses for NY colonies by W. Roelofs (Roelofs et al., 1985).

Pheromone race based on geographical origin (Mason et al., 1996).

${ }^{c}$ Voltine ecotype based on geographical origin (Mason et al., 1996).

${ }^{d}$ Collected by M. Weiss (North Dakota State University). Diapausing larvae maintained in dark at $10^{\circ} \mathrm{C}$ for 120 days and then $30^{\circ} \mathrm{C}, 16: 8$ (L:D)

photophase, with $1 \%$ agar solution for moisture, to break diapause.

e Collected by S. Inch (Selinsgrove, Pennsylvania).

'Laboratory colonies from C. Linn (NY State Ag. Exptl Sta., Cornell University). Colony started from 10 mated pairs and maintained on artificial diet (Roelofs et al., 1985).

${ }^{g}$ Collected by J. VanDynn (North Carolina State University).

${ }^{\mathrm{h}}$ Collected by K. Steffey (University of Illinois).

to South Carolina (Klun \& Huettel, 1988; Mason et al., 1996).

Showers (1993) recognized three European corn borer voltine ecotypes in the USA; northern univoltine, central bivoltine and southern multivoltine. The $E$ pheromone race has bi- and multivoltine ecotypes, whereas the $Z$ race occurs as uni-, bi- and multivoltine ecotypes (Glover et al., 1991). Differences in pheromone blend discrimination between bivoltine $Z$ and univoltine $Z$ males have also been reported (Glover et al., 1987). In New York state, three distinct races occur sympatrically: bivoltine $Z$, univoltine $Z$ and bivoltine $E$ (Roelofs et al., 1985).

Despite the world-wide economic importance of the European corn borer, the population genetics and population structure of this insect species remain largely unknown. The detection and characterization of genetic differentiation among populations is particularly relevant to an understanding of the evolution of a species and to improving pest management practices (Baverstock \& Moritz, 1990). The ability to distinguish amongst geographically distinct populations of European corn borer would allow us to estimate intraspecific levels of gene flow, a critical piece of information for any appropriate management of the development of resistance to insecticides and insecticidal crops (Roush \& Daly, 1990; Tabashnik, 1991; Caprio \& Tabashnik, 1992). Data on the baseline susceptibility of the European corn borer to Bacillus thuringiensis (Bt) across the species range in the USA (Marçon, 1997) show no distinct differences among pheromone races, voltinism types, or geographical location. These data suggest little genetic differentiation among populations, at least in terms of susceptibility to Bt. The limited number of allozyme polymorphisms reported for the European corn borer suggest that genetic differentiation among races and ecotypes is limited (Harrison \& Vawter, 1977; Cardé et al., 1978; Cianchi et al., 1980; Glover et al., 1990).

The purpose of this study was to evaluate levels of genetic divergence among European corn borer races, ecotypes and geographical populations using mitochondrial and nuclear ribosomal ITS regions. Two other crambid species, the smartweed borer, Ostrinia obumbratalis (Lederer) and the south-western corn borer, Diatraea grandiosella Dyar, were included for comparisons of intra- and interspecific variation.

\section{Results}

\section{Pheromone analysis}

The pheromone composition of European corn borer populations with relevant information regarding sample collections is presented in Table 1.

\section{Amplicons}

mtDNA amplicons I, II, III and IV (Table 2) were estimated to be $\approx 333,347,261$ and $624 \mathrm{bp}$ in size, respectively, for $O$. nubilalis as well as for $O$. obumbratalis and $D$. grandiosella. These values are consistent with those predicted by the D. yakuba mtDNA map (Clary \& Wolstenhoime, 1985). The rDNA amplicon $V$ varied in length among the three species, with estimated sizes of $507 \mathrm{bp}$ for the European corn borer, $521 \mathrm{bp}$ for the smartweed borer and $624 \mathrm{bp}$ for the south-western corn borer. 
Table 2. Polymerase chain reaction primers.

\begin{tabular}{|c|c|c|c|c|}
\hline Amplicon & $\begin{array}{l}\text { Forward } \\
\text { primer }^{2}\end{array}$ & Sequence $5^{\prime}-3^{\prime}$ & $\begin{array}{l}\text { Reverse } \\
\text { primer }^{\mathrm{a}}\end{array}$ & Sequence $5^{\prime}-3^{\prime}$ \\
\hline $1^{\mathrm{b}}$ & N1-J-12585 & GGTCCCTTACGAATTTGAATATATCCT & LR-N-12854 & GAGTTCAAACCGGCGTAAGCCAGGT \\
\hline $11^{b}$ & CB-J-11545 & ACATGAATTGGAGCTCGACCAGT & $\mathrm{N} 1-\mathrm{N}-11841$ & GGTACATTACCTCGGTTTCGTTATGAT \\
\hline $111^{\mathrm{c}}$ & N4-J-8502 & GTAGGAGGAGCTGCTATATTAG & N4-N-8718 & GCTTATTCATCGGTTGCTCA \\
\hline IV $^{\mathrm{d}}$ & C1-J-2792 & ATACCTCGACGTTATTCAGA & $\mathrm{C} 2-\mathrm{N}-3380$ & TCAATATCATTGATGACCAAT \\
\hline ITS-1 ${ }^{e}$ & $\mathrm{rDNA}_{2}$ & TTGATTACGTCCCTGCCCTIT & $\mathrm{rDNA}_{1.58 \mathrm{~S}}$ & ACGAGCCGAGTGATCCACCG \\
\hline
\end{tabular}

${ }^{a}$ Mitochondrial primer names follow nomenclature of Simon et al. (1994).

${ }^{b}$ Pruess et al, (1992); 30 cycles: $95^{\circ} \mathrm{C}-30 \mathrm{~s}, 50^{\circ} \mathrm{C}-30 \mathrm{~s}, 70^{\circ} \mathrm{C}-1 \mathrm{~min}$.

${ }^{c}$ Pruess et al. (1992); 30 cycles: $95^{\circ} \mathrm{C}-30 \mathrm{~s}, 45^{\circ} \mathrm{C}-30 \mathrm{~s}, 70^{\circ} \mathrm{C}-1 \mathrm{~min}$.

${ }^{\circ}$ Bogdanowicz et al. (1993) (C1-J-2792), Erney et al. (1996) (C2-N-3380); 30 cycles: $94^{\circ} \mathrm{C}-1 \mathrm{~min}, 50^{\circ} \mathrm{C}-1 \mathrm{~min}, 72^{\circ} \mathrm{C}-2 \mathrm{~min}$

e Vrain et al. (1992) (rDNA $)$, Cherry et al. (1997) (rDNA $\left.{ }_{1.50 s}\right) ; 35$ cycles: $95^{\circ} \mathrm{C}-45 \mathrm{~s}, 52^{\circ} \mathrm{C}-1 \mathrm{~min}, 72^{\circ} \mathrm{C}-2 \mathrm{~min}$.

\section{Restriction fragment length patterns}

Banll, Bsrl and $\mathrm{Mspl}$ did not cut any of the amplicons. Restriction fragment patterns of the four mitochondrial amplicons revealed a total of fifty-three restriction sites in European corn borer and eighty scoreable restric- tion sites among the three species, eighteen in amplicon I, twenty-four in amplicon II, seventeen in amplicon III and twenty-one in amplicon IV. Twenty-six restriction sites were identified in the ITS- 1 amplicon V (Table 3). Mitochondrial and ITS-1 restriction fragment pat-
Table 3. Restriction fragment lengths (bp) estimated on $2.5 \%$ MetaPhor agarose gels for European corn borer (ECB), smartweed borer (SWB), and south-Western corn borer (SWCB).

\begin{tabular}{|c|c|c|c|}
\hline R.E. & ECB & SWB & SWCB \\
\hline Amplicon I & (333 bp) & (333 bp) & (333 bp) \\
\hline$A / u l$ & 350 & 202,130 & 350 \\
\hline Apol & $202,93,18$ & 221,93 & 249,93 \\
\hline Asel & $118,110^{\mathrm{a}}$ & 226,110 & 273,72 \\
\hline Dral & $208,41^{b}$ & $208,49,41^{\mathrm{a}}$ & $231,82,41$ \\
\hline Msel & $103,55,40,30,17$ & $103,55,40^{\mathrm{a}}, 17$ & $110,84,55,48$ \\
\hline Amplicon II & (347 bp) & $(347 \mathrm{bp})$ & $(347 \mathrm{bp})$ \\
\hline Alul & $167,128,45$ & $155,128,45,7$ & 192,142 \\
\hline Apol & $154,110,57,23,18$ & $268,57,18$ & $154,110,99$ \\
\hline Asel & $122,94,63,37,33,8$ & $92,63,52,45,33^{a}, 21,8$ & $122,92,65,33,30,14$ \\
\hline Dral & 290,73 & 268,73 & $247,73,22^{\mathrm{a}}$ \\
\hline Mse $\mathrm{I}^{\mathrm{c}}$ & $59,39,26$ & 39,26 & $91,39,26,15$ \\
\hline Sspl & $181,83,59,17$ & $181,83,46,17$ & 350 \\
\hline Amplicon III & (261 bp) & $(261 \mathrm{bp})$ & (261 bp) \\
\hline Alul & 138,121 & 138,121 & 255 \\
\hline Apol & 194,75 & 194,75 & 262 \\
\hline Asel & $141,88,46$ & $141,88,46$ & $141,70,46,14$ \\
\hline Dral & 154,112 & 154,112 & 262 \\
\hline Msel & $89,66,54,15,10$ & $89,66,54,15,10$ & $89,54,35,32,25,10$ \\
\hline Sspl & $130^{\mathrm{a}}$ & 140,130 & $140,62,35,29$ \\
\hline Amplicon IV & (624 bp) & (624 bp) & $(624 \mathrm{bp})$ \\
\hline$A \mid u l$ & 551,114 & $551,352,174,114$ & 385,198 \\
\hline Apol & $396,156,78$ & $396,156,78$ & $203,187,156,78$ \\
\hline Ase $1^{\mathrm{C}}$ & $225,98,72,64,34,26$ & $225,142,126,98,64$ & $362,101,89,68$ \\
\hline Dral & 357,268 & $357,330,268$ & 330,268 \\
\hline Mse $\mathrm{I}^{c}$ & $98,84,71,51,46,24$ & $101,90,73,50$ & $98,88,73,58$ \\
\hline Sspl & 592,55 & 537,37 & $338,199,96$ \\
\hline Amplicon V & (507 bp) & (521 bp) & $(624 \mathrm{bp})$ \\
\hline Apol & 397,116 & $397,81,45$ & $447,116,65$ \\
\hline Bfal & 517 & 298,228 & 410,210 \\
\hline Dral & 507 & 541 & 491,171 \\
\hline$D p n \|^{c}$ & $131^{a}, 64^{a}, 56,37,27$ & $131^{a}, 64^{a}$ & $433,131,62$ \\
\hline HaellI & 422,99 & 433,99 & 531,99 \\
\hline Hinfl & 504 & 531 & 412,219 \\
\hline Msel & $212,192,104$ & $261,192,35,15,14$ & $235,192,163$ \\
\hline Rsal & $173,138,122,35,16$ & 304,173 & 350,254 \\
\hline Sspl & 481 & 506 & 562,78 \\
\hline Taql & $281,209,30$ & 323,209 & $323,146,80,59$ \\
\hline
\end{tabular}

Total length of amplicon indicated parenthetically.

${ }^{a}$ Interpreted as double band.

b Interpreted as triple band

${ }^{c}$ Pattern difficult to interpret due to the large number of fragments generated and/or loss of small fragments. 


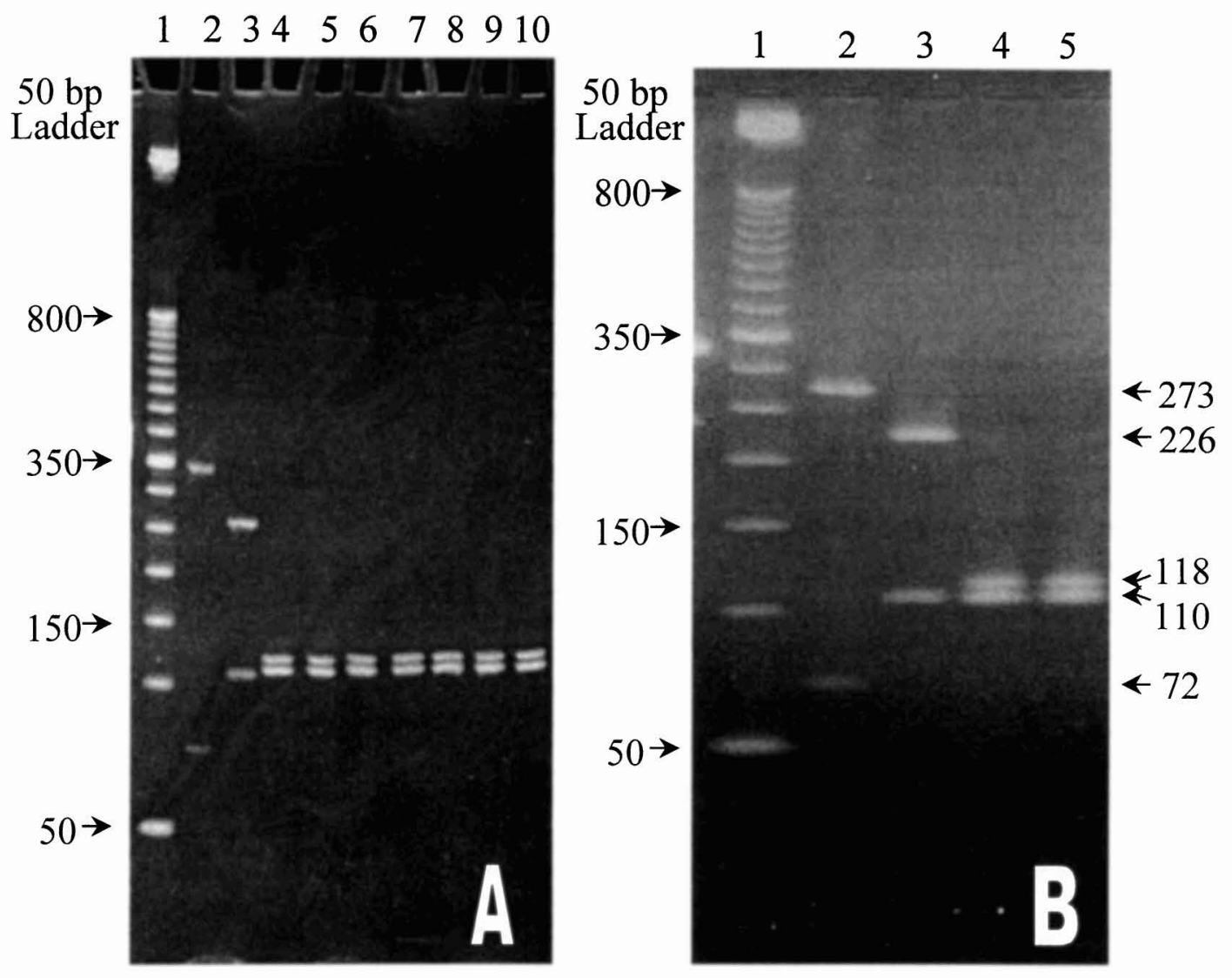

Figure 1. Asel digestion of mitochondrial amplicon I. (A) PAGE (10\%): Lane 1, molecular standard (50 bp ladder); lane 2, D. grandiosella; lane 3 , O. obumbratalis; lanes 4-10, Ostrinia nubilalis (lane 4, Italy; lane 5, North Carolina; lane 6, New York bivoltine E race; lane 7, New York univoltine $Z$ race; lane 8, Pennsylvania; lane 9, North Dakota; lane 10, Nebraska). (B) MetaPhor agarose (2.5\%). Lane 1, molecular standard (50 bp ladder); lane 2, D. grandiosella; lane 3, O. obumbratalis; lane 4-5, Ostrinia nubilalis (lane 4, Italy; lane 5, Nebraska).

terns were identical for all European corn borer samples (Figs 1 and 2). The estimated number of nucleotide substitutions per nucleotide, $d$, calculated from mitochondrial DNA restriction site data ( $\mathrm{Nei} \&$ Tajima, 1981) was 0.043 between the European corn borer and smartweed borer, 0.112 between the European corn borer and south-western corn borer, and 0.106 between the smartweed borer and the southWestern corn borer. Estimates of $d$ from ITS-1 restriction site data were 0.122 between the European corn borer and smartweed borer, 0.160 between European corn borer and south-western corn borer, and 0.158 between smartweed borer and south-western corn borer.

\section{DNA sequence analysis}

ITS-1 sequences were obtained from four European corn borers, two from Nebraska and two from Italy, and two smartweed borers. Sequence data indicate that amplicon $V$ is 505 bp in length for the European corn borer and 497 bp for the smartweed borer (Fig. 3). The size estimate for the intact European corn borer ampli- con, as indicated by the RFLP data ( $507 \mathrm{bp}$ ) is consistent with the corresponding sequence, while the smartweed borer sequence is slightly less than that predicted by RFLP analyses. ITS-1 sequences were identical for the European corn borers from Nebraska and Italy. For the ITS-1 amplicon, the pair-wise absolute distance (Felsenstein, 1993) between the European corn borer and the smartweed borer was 0.17 . All of the restriction patterns observed in the European corn borer and smartweed borer ITS-1 RFLP analyses were supported by RE sites in the corresponding sequences (Fig. 3; Table 3).

\section{Discussion}

The existence of different pheromone races, voltine ecotypes and the geographical distance between European corn borer populations suggests the potential for reproductive isolation and concomitant genetic divergence of populations. However, no genetic divergence was observed among the European corn borer populations we examined. PCR-RFLP patterns for the 


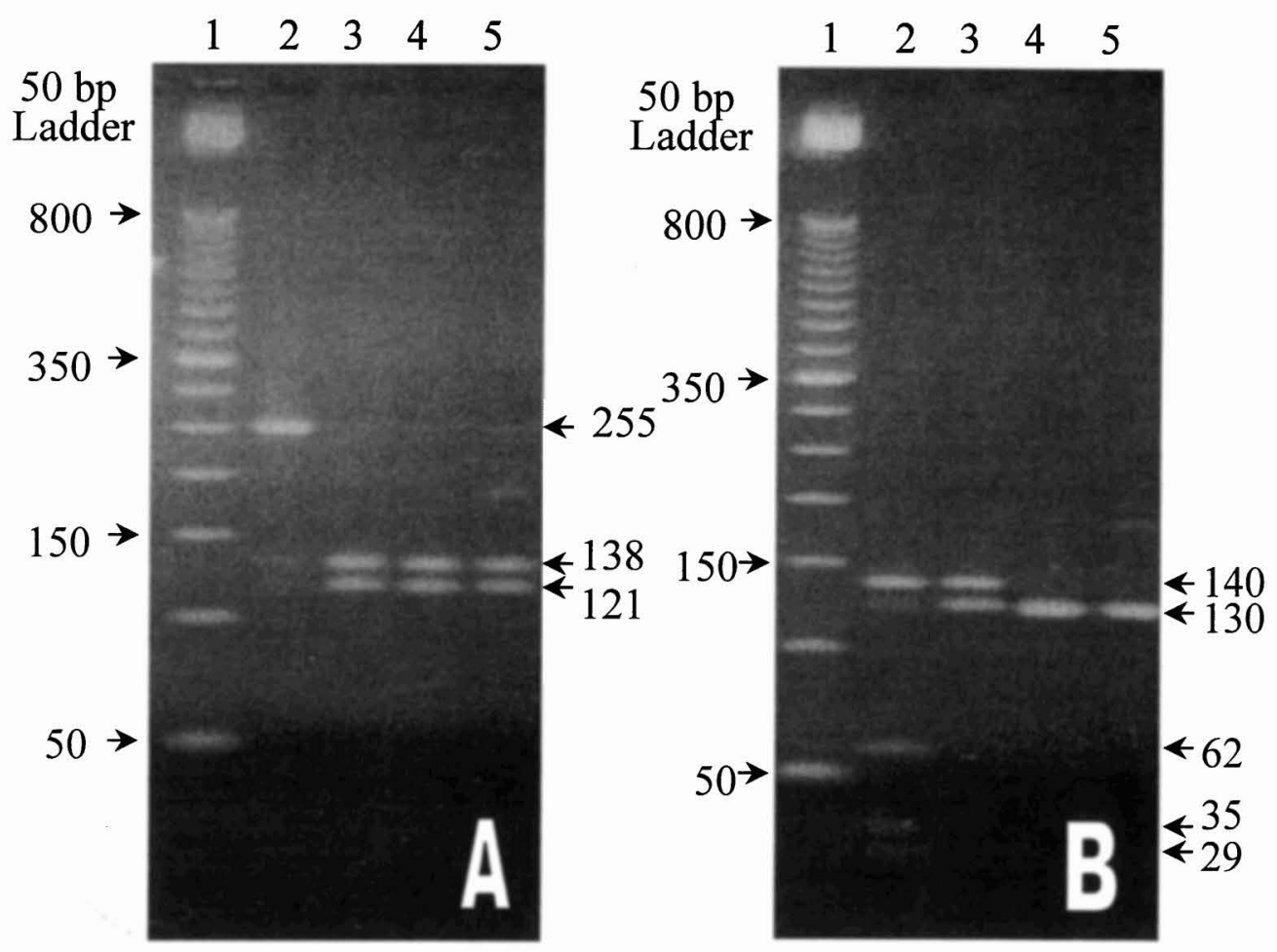

Figure 2. AluI (A) and $S s p I$ (B) digests of mitochondrial amplicon III on a 2.5\% MetaPhor agarose gel. Lane 1, molecular standard (50 bp ladder); lane 2, D. grandiosella; lane 3, O. obumbratalis; lanes 4-5, Ostrinia nubilalis (lane 4, Italy; lane 5, Nebraska).

nuclear and mitochondrial regions were identical and a sequencing of the ITS-1 region confirmed the lack of differentiation (Table 3; Fig. 3). These results support previous allozyme studies which indicate a minimal genetic divergence among European corn borer races and ecotypes (Harrison \& Vawter, 1977; Cianchi et al., 1980; Glover et al., 1990). However, genetic variation in the form of pheromone races (Zhu et al., 1996) and voltine ecotypes (Showers, 1993) has previously been documented. The lack of differentiation among pheromone races and voltine ecotypes from North America and Europe indicates that the evolution of these traits may be a fairly recent event, on an evolutionary time scale. A more extensive survey of European corn borers from various locations in Europe may provide information on the genetic variation in the founding population and additional insight as to the historical basis of the present-day population structure of the European corn borer in North America.

Mitochondrial and ITS sequences are especially useful for detecting genetic divergence in the early stages of speciation and population structure within species. Mitochondrial tree-trimming (Avise et al., 1987) and the concerted evolution of repetitive sequences (Elder \& Turner, 1995) push these regions towards homogeneity in interbreeding populations. However, with the onset of reproductive isolation, both regions have the potential to differentiate relatively rapidly on an evolutionary timescale. Because mitochondrial DNA is primarily inherited from the mother and does not recombine, it can also serve as an excellent marker for identifying populations which may have been isolated historically, but are currently interbreeding (Avise et al., 1987; Taylor et al., 1996b). The homogeneity of the mitochondrial and ITS-1 sequences observed in European corn borer indicates that the pheromone races and voltinism ecotypes have evolved relatively recently $(<10000-100000$ years ago). A generally accepted estimate for mtDNA divergence is $2 \%$ per million years (Powell et al., 1986). Based upon our ITS-1 and mitochondrial RFLP data for the European corn borer and smart weed borer, the ITS-1 amplicon has diverged 3-4-fold faster than the mitochondrial amplicons. Given a divergence rate of $7 \%$ per million years, we expect one fixed nucleotide difference approximately every 30000 years in a 500 bp ITS-1 sequence.

In a few of our RFLP patterns, the sum of the fragment sizes do not equal the size of the amplified region. This is not uncommon in RFLP analyses, particularly for REs with a large number of restriction sites (Roehrdanz et al., 1994). Such REs can generate very small, undetectable, DNA fragments as well as comigrating fragments of similar sizes. This is particu- 


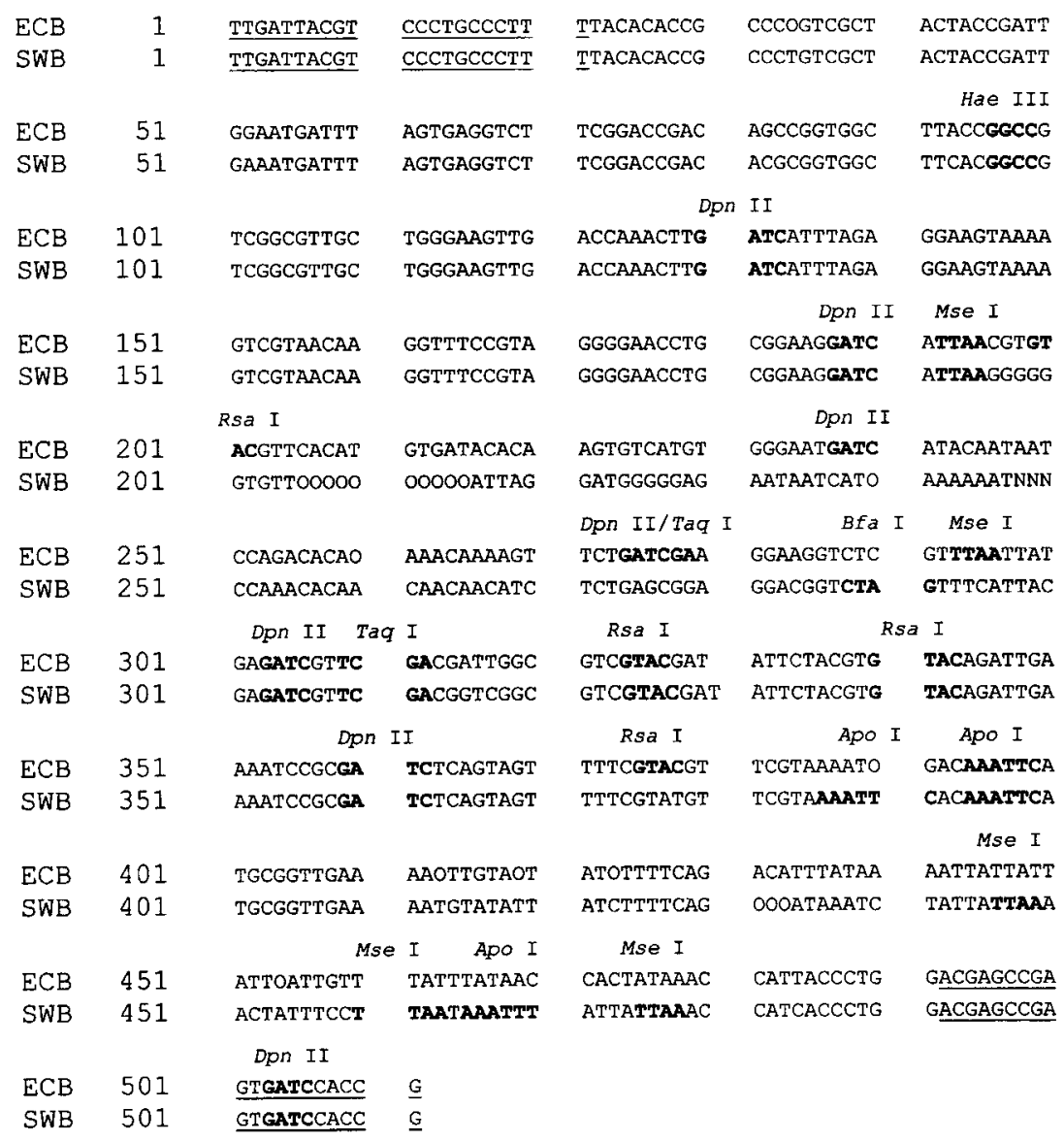

even among different species within the genus Ostrinia. The genetic distance calculated from nuclear PCRRFLPS of the ITS-1 region was threefold greater than that calculated from PCR-RFLPs of mitochondrial amplicons. This faster rate of divergence was confirmed by sequencing data (Fig. 3), suggesting that the nuclear ITS-1 marker should provide a greater power to detect differences among European corn borer populations. Information from ITS-1 PCR-RFLPs and DNA sequences yielded essentially the same results. Therefore, PCR-RFLP may be preferable for population genetics studies, because many more individuals can be surveyed quickly and at less cost (Simon et al., 1993; Taylor et al., 1996a).

Low levels of mtDNA variation among widely dispersed populations has been reported among populations of other insect species, such as gypsy moth, Lymantria dispar (L.) (Harrison et al., 1983), horn fly, Haematobia irritans (L.) (McDonald et al., 1987), stable fly, Stomoxys calcitrans (L.) (Szalanski et al., 1996), secondary screwworm, Cochliomyia macellaria (Taylor et al., 1996b), monarch butterfly, Danaus plexippus L. (Brower \& Boyce, 1991), and tobacco budworm, Heliothis virescens (F) (Roehrdanz et al., 1994). These species all share high gene flow or a 
recent expansion from a genetic bottleneck. These factors may also contribute to the lack of genetic variation observed among European corn borer populations. The sporadic movement of the European corn borer on surface airflow currents has been documented (Showers et al., 1995), and it is possible that gene flow is contributing to the maintenance of genetic similarity among widely dispersed European corn borer populations. From a resistance management standpoint, an important consequence would be the potential for the rapid spread of insecticide resistance genes from one location throughout the species' geographical range (Caprio \& Tabashnik, 1992).

\section{Experimental procedures}

Insects

European corn borer adults used for the genetic analyses were obtained from six locations across the USA and one location in northern Italy, representing different voltinism and pheromone strains (Table 1). For most of the locations, European corn borer were field-collected as larvae and shipped to our laboratory by overnight mail. Larvae were reared to adults, frozen and stored at $-80^{\circ} \mathrm{C}$. The European corn borer samples from New York were obtained from laboratory colonies as pupae (C. Linn, New York State Agricultural Experiment Station, Cornell University, Ithaca, NY). Pupae were reared to adults, frozen, and stored at $-80^{\circ} \mathrm{C}$.

Two other crambid species, the smart weed borer, $O$. obumbratalis (Lederer) and the south-western corn borer, $D$. grandiosella Dyar were analysed for comparison. Smart weed borers were field-collected as adults from weedy patches in Polk County, lowa and delivered as live moths to the University of Nebraska. South-western corn borers were obtained as pupae from a laboratory colony maintained by the USDA-ARS Cotton Insects Research Unit, Starkville, Mississippi. This colony was initiated from insects collected in corn fields throughout Mississippi and is annually infused with wild insects (Frank M. Davis, personal communication).

\section{Pheromone analysis}

Fifth instar larvae were sent to the University of Delaware for pheromone gland analysis to determine the percentage of $E$ and $Z$ pheromone alleles. Larvae were reared to adults and pheromone glands were excised from adult females during the 7 th hour of scotophase on the second day after eclosion. Each gland was extracted for at least $30 \mathrm{~min}$ in $5 \mu \mathrm{L}$ heptane containing $Z$-7-tetradecenyl $(0.9 \mathrm{ng} / \mu \mathrm{L})$ acetate as an internal standard. Samples $(3 \mu \mathrm{L})$ were analysed by gas chromatography on a $15 \mathrm{~m} \times 0.25 \mathrm{~mm}$ i.d. fused silica capillary column containing a $0.5 \mu \mathrm{m}$ film of Stabilwax (Restek Corporation). A Varian 3500 gas chromatograph (Varian Associates) equipped with a split/ splitless injector, autosampler and flame ionization detector was used for all analyses. The column oven was programmed at $80^{\circ} \mathrm{C}$ for $1.5 \mathrm{~min}, 80-130^{\circ} \mathrm{C}$ at $20^{\circ} / \mathrm{min}, 130-210^{\circ} \mathrm{C}$ at $7^{\circ} \mathrm{C} /$ $\mathrm{min}, 210-245^{\circ} \mathrm{C}$ at $20^{\circ} / \mathrm{min}$ and $245^{\circ} \mathrm{C}$ for $5 \mathrm{~min}$. The injector temperature was $200^{\circ} \mathrm{C}$, detector temperature was $250^{\circ} \mathrm{C}$, and nitrogen flow was $19 \mathrm{~cm} / \mathrm{s}$. The $E$ and $Z$ isomers were identified based on co-elution with known standards. The internal standard and two pheromone isomers eluted at $\approx 15 \mathrm{~min}$, with peaks of interest being separated by $0.2 \mathrm{~min}$.

Female moths were assigned to pheromone strains by the ratio of the two pheromone isomers. Percentages were determined by a comparison of isomer peak heights at appropriate retention times. Samples with $>85 \% E$ isomer were classified as $E$ strain, those with $50-80 \% E$ isomer were classified as hybrids, and those with the $E$ isomer $<15 \%$ were classified as $Z$ strain.

\section{PCR-RFLP}

Procedures were carried out according to the methods of Taylor et al. (1996a), with minor modifications. Adult thoraces were individually homogenized in $100 \mu \mathrm{L}$ of lysis buffer. Proteinase $\mathrm{K}$ and RNAase were increased to 20 and $10 \mu \mathrm{g}$, respectively. DNA was isolated by phenol/chloroform extraction using quantities one half those of Taylor et al. (1996a). DNA was resuspended in 50-100 $\mu \mathrm{L}$ of TE buffer. After the extractions, DNA presence and quality was confirmed with $1 \%$ agarose gels. Samples were stored at $4^{\circ} \mathrm{C}$ for subsequent analysis.

Because mtDNA sequence information was not available for the European corn borer, an initial screen of potential mitochondrial primers was performed and four primer pairs were chosen which produced reliable and consistent DNA amplification products (amplicons) (Table 2). Based upon the Drosophila yakuba mitochondrial genome (Clary \& Wolstenholme, 1985), the expected length and content of the amplicons were: amplicon I, 320 base pairs (bp) containing the $3^{\prime}$ end of the NADH dehydrogenase (NADHDH) 1 gene, the entire tRNA $A_{\text {Leu }}$ gene, and the $5^{\prime}$ end of the 16s rRNA gene; amplicon II, 345 bp containing the $3^{\prime}$ end of the cytochrome $B$ gene, the entire tRNA ${ }_{\text {Ser }}$ gene and the $5^{\prime}$ end of the NADHDH 1 gene; amplicon III, 257 bp containing part of the NADHDH 4 gene; amplicon IV, 628 bp containing the $3^{\prime}$ end of the cytochrome oxidase (CO) I gene, the entire tRNA $A_{L e u}$ gene and the $5^{\prime}$ end of the CO II gene. Primers rDNA $\mathrm{A}_{2}$ and $\mathrm{rDNA}_{1.58 \mathrm{~S}}$ (Table 2) were used to amplify a region of the nuclear ribosomal DNA (rDNA) which includes a portion of the $18 \mathrm{~s}$ rDNA gene, the internally transcribed spacer 1 (ITS-1), and a portion of the $5.8 \mathrm{~s}$ rDNA gene (Vrain et al., 1992; Cherry et al., 1997).

Fifteen restriction enzymes (A/ul, Apol, Asel, Banll, Bfal, Bsrl, Dpnll, Dral, Haell, Hinfl, Msel, Mspl, Rsal, Sspl and Taql (New England Biolabs) were screened on five adult $O$. nubilalis from each of the seven populations-five adult $O$. obumbratalis, and five adult $D$. grandiosella. Restriction enzyme digests followed the manufacturer's recommended procedures. Reaction mixtures contained $1 \mu \mathrm{L}$ of PCR product, $0.2 \mu \mathrm{L}$ of restriction enzyme, $0.5 \mu \mathrm{L}$ of $10 \mathrm{X}$ buffer, and autoclaved double-distilled water to a total volume of $5 \mu \mathrm{L}$. Samples were incubated at $37^{\circ} \mathrm{C}$ for $18-24 \mathrm{~h}$. Restriction fragments were separated by polyacrylamide $(10 \%)$ and Metaphor (FMC Bioproducts) agarose $(2.5 \%)$ gel electrophoresis. A 50 bp ladder was included on each gel. Fragment sizes were estimated with GEL-JLM (LaCroix, 1994). A matrix of restriction site presence/ absence was derived manually from the restriction fragment patterns without explicitly mapping RE sites. Restriction fragment patterns which could not be explained by the gain or loss of individual restriction sites were considered not scoreable and were not included in the among species restriction site analysis. 


\section{DNA sequencing}

The ITS-1 amplicon was sequenced from four European corn borers (two from Nebraska and two from Italy) and two smartweed borers. Amplified DNA was purified using the Prep-AGene DNA purification kit (Bio-Rad) and resuspended in double-distilled water to a final concentration of $30 \mathrm{ng} / \mu \mathrm{L}$. Sequencing was performed via the dideoxy chain termination method (Sanger et al., 1977) by the lowa State University DNA Sequencing Laboratory (Ames, lowa). Two primers, $\mathrm{rDNA}_{2}$ and $\mathrm{rDNA}_{1.58 \mathrm{~s}}(5 \mathrm{pmol} / \mu \mathrm{L})($ Table 2$)$, were used to sequence in both directions. Sequences were aligned manually. A computer program, DIGEST (Ramin Nakisa, unpublished data), was used to scan the DNA sequences for restriction sites. Nucleotide sequences for European corn borer and smart weed borer have been deposited in GENBANK with accession numbers AF077013 and AF077014.

\section{Statistical analysis}

Nucleotide sequence divergence $(d)$ was calculated from the restriction site data using the Restriction Enzyme Analysis Package (REAP) (McElroy et al., 1992) following the procedures of Nei \& Tajima (1981) and Nei \& Miller (1990). Pair-wise absolute distances $(d)$ between species were calculated from DNA sequence data using the Dnadist module of PHYLIP 3.5 (Felsenstein, 1993).

\section{Acknowledgements}

The authors wish to acknowledge the contributions of R. Peterson for technical advice, K. Pruess and A. Szalanski for providing the PCR primers and for their critical review of an earlier draft of this manuscript. Field collections were provided by K. Steffey (University of Illinois), M. Weiss (North Dakota State University), J. VanDuyne (North Carolina State University), S. Inch, P. Inch (Selinsgrove, Pennsylvania), and laboratory populations were provided by $\mathrm{C}$. Linn (Cornell University). Funding for this work was provided by the University of Nebraska Center for Biotechnology, and CAPES (Brazilia, Brazil). This research was part of the North Central Regional Research Project, NC-205, Ecology and management of European corn borer and other stalk-boring Lepidoptera.

\section{References}

Avise, J.C., Arnold, J., Ball, R.M., Bermingham, E., Lamb, T., Neigel, J.E., Reeb, C. and Saunders, N. (1987) Intraspecific phylogeography: the mitochondrial DNA bridge between population genetics and systematics. Ann Rev Ecol Syst 18: 489-522.

Azeredo-Espin, A.M.L., Schroder, R.F.W., Huettel, M.D. and Sheppard, W.S. (1991) Mitochondrial DNA variation in geographic populations of Colorado potato beetle, Leptinotarsa decem/ineata (Coleoptera: Chrysomelidae). Experientia 47: 483-485.

Baverstock, P.R. and Moritz, C. (1990) Sampling design. Molecular Systematics (Hillis, D.M. and Moritz, C., eds.), pp. 13-24. Sinauers Associates Inc., Sunderiand, MA.
Beck, S.D. (1987) Developmental and seasonal biology of Ostrinia nubilalis. Agric Zool Rev 2: 59-96.

Bogdanowicz, S.M., Wallner, W.E., Bell, J., Odell, T.M. and Harrison, R.G. (1993) Asian gypsy moths (Lepidoptera: Lymantriidae) in North America: evidence from molecular data. Ann Entomol Soc Am 86: 710-715.

Boyce, T.M., Zwick, M.E. and Aquadro, C.F. (1989) Mitochondrial DNA in the bark weevils: size, structure, and heteroplasmy. Genetics 123: 825-832.

Brower, A.V.Z. and Boyce, T.M. (1991) Mitochondrial DNA variation in monarch butterflies. Evolution 45: 1281-1286.

Caprio, M.A. and Tabashnik, B.E. (1992) Gene flow accelerates local adaptation among finite populations: simulating the evolution of insecticide resistance. J Econ Entomol 85: 611-620.

Cardé, R.T., Roelofs, W.L., Harrison, R.G., Vawter, A.T., Brussard, P.F., Mutura, A. and Munroe, E. (1978) European corn borer: Pheromone polymorphism or sibling species? Science 199: 555-556.

Cherry, T., Szalanski, A.L., Todd, T.C. and Powers, T.O. (1997) The internal transcribed spacer region of Belonolaimus (Nemata: Belonolaimidae). J Nematol 29: 23-29.

Cianchi, R., Maini, S. and Bullini, L. (1980) Genetic distance between pheromone strains of the European corn borer, Ostrinia nubilalis: Different contributions of variable substrate, regulatory and non regulatory enzymes. Heredity 45: 383-388.

Clary, D.O. and Wolstenholme, D.R. (1985) The mitochondrial DNA molecule of Drosophila yakuba: nucleotide sequence, gene organization, and genetic code. J Mol Evol 22: 252-271.

DuRant, J.A., Fescemyers, H.W., Mason, C.E. and Udayagiri, S. (1995) Effectiveness of four blends of European corn borer (Lepidoptera: Pyralidae) sex pheromone isomers at three locations in South Carolina. J Agric Entomol 12: 241-253.

Elder, J.F. and Turner, B.J. (1995) Concerted evolution of repetitive DNA sequences in eukaryotes. Q Rev Biol 70: 297-320.

Erney, S.J., Pruess, K.P., Danielson, S.D. and Powers, T.O. (1996) Molecular differentiation of alfalfa weevil strains (Coleoptera: Curculionidae). Ann Entomol Soc Am 89: 804-811.

Felsenstein, J. (1993) PHYLIP: Phylogeny inference package, Version 3.5. University of Washington, Seattle, WA

Glover, T.J., Campbell, M.G., Robbins, P.S. and Roelofs, W.L. (1990) Sex-linked control of sex pheromone behavioral responses in European corn borer moths (Ostrinia nubilalis) confirmed with TPI marker gene. Arch Insect Biochem Physiol 15: 67-77.

Glover, T.J., Knodel, J.J., Robbins, P.S., Eckenrode, C.J. and Roelofs, W.L. (1991) Gene flow among three races of European corn borers (Lepidoptera: Pyralidae) in New York State. Environ Entomol 20: 1356-1362.

Glover, T.J., Tang, X.-H. and Roelofs, W.L. (1987) Sex pheromone blend discrimination by male moths from $E$ and $Z$ strains of European corn borer. J Chem Ecol 13: 143-151.

Harrison, R.G. and Vawter, A.T. (1977) Allozyme differentiation between pheromone strains of the European corn borer, Ostrinia nubilalis. Ann Entomol Soc Am 70: 717-720.

Harrison, R.G., Wintermeyer, S.F. and Odell, T.M. (1983) Patterns of genetic variation within and among gypsy moth, Lymantria dispar (Lepidoptera: Lymantriidae), populations. Ann Entomol Soc Am 76: 652-656.

Klun, J.A. and Huettel, M.D. (1988) Genetic regulation of sex pheromone production and response: interaction of sympatric pheromonal races of the European corn borer, Ostrinia nubilalis (Lepidoptera: Pyralidae). J Chem Ecol 14: 2047-2061. 
LaCroix, J.M. (1994) DNA fragment size determination on agarose gel by using the application GEL. Comp App Biosci 10: 185-187.

Liebherr, J. and Roelofs, W. (1975) Laboratory hybridization and mating period studies using two pheromone strains of Ostrinia nubilalis. Ann Entomol Soc Am 68: 305-309.

Marçon, P.C.R.G. (1997) Baseline susceptibility to Bacillus thuringiensis toxins and population genetics of the European corn borer, Ostrinia nubilalis (Hübner) (Lepidoptera: Pyralidae). PhD Dissertation, University of Nebraska, Lincoln, Nebraska.

Mason, W.D., Witkowski, J.F., Higgins, R.A., Onstad, D.W. and Dively, G.P. (1996) European corn borer ecology and management. North Cent. Reg. Publication 327, lowa State University, Ames, lowa.

McDonald, P.T., Hilburn, L.R. and Kunz, S.E. (1987) Genetic similarities among natural populations of the horn fly (Diptera: Muscidae). Ann Entomol Soc Am 80: 288-292.

McElroy, D., Moran, P., Bermingham, E. and Kornfield, I. (1992) REAP: an integrated environment for the manipulation and phylogenetic analysis of restriction data. $J$ Hered 83: 157-158.

Munroe, E. (1976) Fasc. 13.2A. Pyraloidea (in part). The Moths of America North of Mexico (Dominick, R.B., Dominick, T., Ferguson, D.C., Franglemont, J.G., Hodges, R.W. and Munroe, E., eds.), pp. 1-78. E.W. Classey Ltd and the Wedge Entomol. Res. Foundation, London.

Nei, M. and Miller, J.C. (1990) A simple method for estimating average number of nucleotide substitutions within and between populations from restriction data. Genetics 125: 873-879.

Nei, M. and Tajima, F. (1981) DNA polymorphisms detectable by restriction endonucleases. Genetics 97: 145-163.

Powell, J.R., Caccone, A., Amato, G.D. and Yoon, C. (1986) Rates of nucleotide substitution in Drosophila mitochondrial DNA and nuclear DNA are similar. Proc Natl Acad Sci USA 83: 9090-9093.

Pruess, K.P., Zhu, X. and Powers, T.O. (1992) Mitochondrial transfer RNA genes in a black fly, Simulium vittatum (Diptera: Simuliidae), indicate long divergence from mosquito (Diptera: Culicidae) and fruit fly (Diptera; Drosophilidae). J Med Entomol 29: 644-651.

Roehrdanz, R.L., Lopez, J.D., Loera, J. and Hendricks, D.E. (1994) Limited mitochondrial DNA polymorphism in North America populations of Heliothis virescens (Lepidoptera: Noctuidae). Ann Entomol Soc Am 87: 856-866.

Roelofs, W., Du, J.W., Tang, X.H., Robbins, P.S. and Eckenrode, C.J. (1985) Three European corn borer populations in New York based on sex pheromones and voltinism. J Chem Ecol 11: 829836.

Roelofs, W., Glover, T., Tang, X., Sreng, I., Robbins, P., Eckenrode, C.J., L'fstedt, C., Hansson, B.S. and Bengtsson, B.O. (1987) Sex pheromone production and perception in European corn borer moths is determined by autosomal and sex-linked genes. Proc Natl Acad Sci USA 84: 7585-7589.

Roush, R.T. and Daly, J.C. (1990) The role of population genetics in resistance research and management. Pesticide Resistance in
Arthropods (Roush, R.T. \& Tabashnik, B.E., eds), pp. 97-152. Chapman \& Hall, New York.

Sanger, F., Nicklen, S. and Coulson, A.R. (1977) DNA sequencing with chain termination inhibitors. Proc Natl Acad Sci USA 74: 5436-5437.

Showers, W.B. (1993) Diversity and variation of European corn borer populations. Evolution of Insect Pests/Patterns of Variation (Kim, K.C. and McPheron, B.A., eds), pp. 287-309. John Wiley \& Sons, New York.

Showers, W.B., Weiss, M.J., Derrick, M.E. and Hendrix, W.H. III (1995) Potential movement on surface airflow of a bivoltine population of European corn borer (Lepidoptera: Pyralidae) into a historically univoltine habitat. Environ Entomol 24: 835840.

Simon, C., Frati, F., Beckenback, A., Crespi, B., Liu, H. and Flook, P. (1994) Evolution, weighting, and phylogenetic utility of mitochondrial gene sequences and a compilation of conserved polymerase chain reaction primers. Ann Entomol Soc Am 87: 651-701.

Simon, C., Mclntosh, C. and Deniega, J. (1993) Standard restriction fragment length analysis of the mitochondrial genome is not sensitive enough for phylogenetic analysis or identification of 17-year periodical cicada broods (Hemiptera: Cicadidae): potential for a new technique. Ann Entomol Soc Am 86: 228-238.

Szalanski, A.L., Taylor, D.B. and Peterson, R.D. II (1996) Population genetics and gene variation of stable fly populations (Diptera: Muscidae) in Nebraska. J Med Entomol 33: 413-420.

Tabashnik, B.E. (1991) Managing resistance to Bacillus thuringiensis: lessons from the diamondback moth (Lepidoptera: Plutellidae). J Econ Entomol 84: 49-55.

Taylor, D.B., Szalanski, A.L. and Peterson, R.D. II (1996a) Identification of screwworms species by polymerase chain reactionrestriction fragment length polymorphism. Med Vet Entomol 10: 63-70.

Taylor, D.B., Szalanski, A.L. and Peterson, R.D. If (1996b) Mitochondrial DNA variation in screwworm. Med Vet Entomol 10: 161169.

Valle, L.S. and Azeredo-Espin, A.M.L. (1995) Mitochondrial DNA variation in two Brazilian populations of Cochliomyia macellaria (Diptera: Calliphoridae). Braz J Genet 18: 521-526.

Vinal, S.C. (1917) The European corn borer, Pyrauta nubilalis Hübner, a recently established pest in Massachusetts. Massachusetts Agric Exp Stn Bull 178: 147-152.

Vrain, T.C., Wakarchuk, D.A., Levesque, A.C. and Hamilton, R.I. (1992) Intraspecific rDNA restriction fragment length polymorphism in the Xiphinema americanum group. Fund Appl Nematol 15: 563-573.

Zhu, J., L'fstedt, C. and Bengtsson, B.O. (1996) Genetic variation in the strongly canalized sex pheromone communication system of European corn borer, Ostrinia nubilalis (Hübner) (Lepidoptera: Pyralidae). Genetics 144: 757-766. 